\title{
Household Access to Drinking Water Sources in the Bergas District Industrial Center, Semarang Regency Central Java Province Indonesia
}

\author{
Puji Hardati $^{1}$, R. Rijanta ${ }^{2}$, Su Ritohardoyo ${ }^{3}$ \\ \{puji.hardati@mail.unnes.ac.id ${ }^{1}$, rijanta@ugm.ac.id ${ }^{2}$ surito@ugm.ac.id ${ }^{3}$ \} \\ ${ }^{1}$ Department of Geography Faculty of Social Sciences Semarang State University, Indonesia \\ ${ }^{2,3}$ Faculty of Geography Gajahmada University, Indonesia
}

\begin{abstract}
The need for drinking water is increasingly proportional to the increasing population, while the source of drinking water is increasingly limited both in quantity and quality. The sustainable development goal requires that each region of the country be able to meet the needs of drinking water. How access to drinking water sources is still one of the problems faced by some residents. This study aims to examine the main sources of drinking water used by households in the central area of industrial activity. The research was carried out in the Central area of industrial activity in Semarang Regency. The study population was households and samples were taken by purposive random sampling. The research variables are the types of household drinking water sources and the number of households. Data analysis used descriptive percentages on each type of drinking water source. The results of the study showed that there was a transformation of household drinking water source access. Some households use bottled water for drinking water, with practical and easily accessible reasons. While there are still households that use drinking water from unprotected springs, even though the number is only around 5 percent.
\end{abstract}

Keywords: Sustainable Development Goals, Sources of Drinking Water, Unprotected Springs, Industrial Center Area.

\section{Introduction}

World population is increasing, with uneven distribution. The population in developed countries is about one third in developing countries, around two thirds. As an illustration, in 2015 the world population reached 7.336 million people, in developed countries 1,254 billion people and in developing countries 6,082 billion people [1], [2]. The population in the Asian Continent reached 4.397 billion people or around 59.94 percent. Indonesia is one of the countries in Asia with a population of 255,182 million [3], [4]

In Indonesia, the population has also increased, over the past fifteen years from 2000 to 2015, the population has increased by around 50.06 million [3]. In addition to increasing population, the distribution is not evenly distributed. On the island of Java with an area of 6.77 percent of Indonesia's total area, it has a population of 56.8 percent, while outside Java the area is 93.23 percent, the population is 43.2 percent. On the island of Java, the majority of the population is in West Java Province (18.29 percent), then East Java Province (15.22 percent), and Central Java Province 15.22 percent [2], [3].

The increasing population is followed by the increase in the amount of water needs that must be met. Found that population dynamics have a very important influence on the ecosystem, including the availability of water [4]. High population growth and density can 
have implications for access to clean water and decent drinking water. The world is experiencing a shortage of water to meet clean water needs. Although there is a potential for abundant water availability, it is still common to find people who have difficulty accessing and meeting water needs for everyday life [5], [6]. In Indonesia, not all residents have access to clean water, around 49 percent can access clean water properly [7]. In Central Java, some of the residents who are included in poor households have difficulty getting access to clean water [8]. Some regions with different access to clean water have a positive effect on population dynamics, population health [9]-[13].

The need for clean water and decent drinking water is very crucial. The global development goals, which are started from millennial development goals (MDGs) that take place over the period 2000-2015, are continued with the goals of sustainable development or SDGs during 2016-2030. The development goals are universal collective agreements, without exception and for all. In the document, it states that clean water is still a problem for the population and is proclaimed in the purpose of the development, namely on the 6th destination [14] . In addition, international agreements, rights to water are strengthened in the UN Development of Human Right of Water, that human rights to water are needed to ensure dignified human life [15], [16]). In Indonesia, it is agreed and stipulated in the 2015-2019 National Medium-Term Development Plan, through increasing access to decent drinking water services in 2019 [17].

The issue of access to drinking water still needs attention, so the purpose of this discussion is specifically on access to household drinking water at the central location of industrial activities. Industrial areas require more water than other natural areas. It is hoped that this study can inspire all parties that water sources must be conserved so that access to drinking water needed by every resident can be fulfilled in their environment, without having to bring in from outside the region.

\section{Literature Review}

The purpose of the literature studied includes the goals of sustainable development and access to household drinking water sources. Furthermore, it is expected to be the basis of the literature in the study discussion.

\subsection{Sustainable Development Goals}

The Sustainable Development Goals, abbreviated as the SDGs, are one of the global agendas agreed upon to improve universal population welfare. In the agreement, that sustainable development had 17 objectives, with 169 targets. The sustainable development goals are mutually integrated and cannot be separated from each other, and try to balance the three dimensions of sustainable development, namely economic, social and environmental dimensions [14], [18].

The goal of sustainable development includes all things that are very ambitious, with a vision of a world free from poverty, hunger, disease and greed, all life can thrive. A world free from fear and violence. A world with universal reading skills. The world with equal and universal access to quality education, at every level, towards health services and social protection, so that physical, mental and social welfare is guaranteed. Dominating for drinking water and sanitation rights, clean, adequate, safe, affordable and nutritious environment. 
Human habitat is safe, sustainable and sustainable, and universal access to affordable, reliable and sustainable energy [14], [17]-[19].

Based on the vision of sustainable development, it is clear and explicit that access to drinking water is one of the goals of sustainable development. It is clearly stated in the sixth objective, namely ensuring the availability and management of sustainable water and sustainable sanitation for all [4]. Furthermore, in the sixth objective, in its implementation, Indonesia made a translation document for sustainable development goals, in the sixth objective, explained with 7 targets, and number one target with 10 indicators, and indicator number one read: proportion of population using drinking water managed secure; target number two reads: the percentage of households that have access to drinking water source services is feasible, target number four reads: the proportion of the population that has access to safe and sustainable drinking water source services[14], [20].

\subsection{Access to Household Drinking Water Sources}

Clean water is safe or healthy and well-drunk, colorless, odorless, with fresh taste, and is used every day for washing, bathing, cooking, and drinking after cooking [19], [21] . Healthy water is water that does not endanger the health of its users [22].

The most important water needs for humans are drinking water, so it needs to be met in quantity and quality. The need for drinking water every day for humans is around 30-120 liters per day. Drinking water needs differ between developed and developing countries, for developed countries 60-120 liters per day and developing countries 30-60 liters per day [20], [23].

Based on the type of water requirements for humans, water is divided into two, namely domestic and non-domestic water. Domestic water is water used to meet household water needs, while non-domestic water is water needs related to human activities, such as for agricultural activities, industry, tourism, public places, places of worship, and others [21]. Whereas the supply and supply of clean water is carried out by PDAMs used by piping and non-piping connections.

\section{Research Method}

The research location is in the central industrial area of Bergas District, Semarang Regency. Bergas District is one of the areas which is the center of industrial development in Semarang Regency. The location is directly adjacent to the city of Semarang, the capital city of Central Java Province, so it becomes the choice of residents to stay.

The study population was houses in the Bergas District. The number of houses that became the study population was 20,149 houses. All populations are subjected to analytical research, so the research is population research. The analysis unit is households found in Bergas District. The research variable that is expected to explain the research objectives is the type of household drinking water source. The main source of research data is secondary data originating from the service. Related agencies, such as the central statistics agency, the public works copyright works, regional development planning bodies.

Data analysis was done by descriptive method, table analysis, and drawing. Descriptive analysis based on the percentage of each type of household water source access to the number of households. The percentage formula is formulated as follows.

Phwsa $=($ ntwsu $):(n h) \times 100$ percent. 
Phwsa: percentage of household water source access

ntwsu: number of types of water sources used

nh: number of households

100: units in percent.

\section{Result and Discussion}

The results and discussion contain the accessibility of the research area, the number and dynamics of the population, access to household drinking water resources. Each is explained as follows.

\subsection{Civil Society}

The study was conducted in Bergas District, Semarang Regency, is one of the central areas of industrial activity. The area consists of 13. villages. Administratively, the location is in the northern part of the Semarang Regency area. North side next to Ungaran Barat and Ungaran Timur Districts; the south is bordered by Bandungan and Bawen Subdistricts; in the west it borders on Kendal Regency, and on the east it borders Pringapus District (administrative map of Bergas District).

Absolute location is located at 701948 - 701578 South Latitude and 11003930 - 110046 81 East Longitude. The location is on a highway crossing that connects the city of Semarang with the City of Surakarta and Yogyakarta, so it has high accessibility and is easily accessible, known as the location of Joglosemar [24], [25].

Amount of population growth and density The population in Bergas District during the last decade, 2010-2017 experienced fluctuating changes, from 68,241 people to 67,213. During this period, population growth increased by 0.44 percent. In 2010 population growth was 0.42 percent and in 2014 it was 0.98 percent.

Table 1. Growth and Dencity Population in Bergas District, Semarang Regency, 2010-2017.

\begin{tabular}{|l|l|c|l|}
\hline Year & $\begin{array}{l}\text { Population } \\
\text { (Soul) }\end{array}$ & Population Density (Soul/Km2) & $\begin{array}{l}\text { Population } \\
\text { Growth }(\%)\end{array}$ \\
\hline 2010 & 68,241 & 1,441 & 0,42 \\
2011 & 68,942 & 1,457 & 1,03 \\
2012 & 69,570 & 1,470 & 0,91 \\
2013 & 70,191 & 1,483 & 0,89 \\
2014 & 70,862 & 1,497 & 0,96 \\
2015 & 71,411 & 1,504 & 0,77 \\
2016 & 82,412 & 1,741 & $*$ \\
2017 & 67,213 & 1,420 & $*$ \\
\hline
\end{tabular}

Source: Statistic Central Bureau Semarang Regency

* : not state

\subsection{Number of Houses and Access to Drinking Water Sources}

The increasing number of residents is always followed by the number of houses. The number of houses in Bergas Subdistrict in 2010 was 19,534, increasing to 20,149, for four years there was an increase in the number of houses by 615 or an average of 214 fruits per year or around 25 percent. Based on the quality of building houses, there are still houses with quality non-permanent buildings, namely 15,67 percent. During the period of 2000-2014 there 
was an increase in the number of non-permanent houses, from 3062 to 3154, or 98 or on average each year there were 27 permanent houses.

The increase in the number of non-permanent houses can be explained that there are still residents who have not been able to make permanent homes. In fact, permanent homes are one of the health requirements for prosperity. This is in accordance with the mandate that has been formulated in the goals of sustainable development (SDGs).

Access to drinking water sources in each house varies, from bottled water, plumbing, pumps, wells, protected springs and unprotected springs. Unprotected water sources consist of two types, namely unprotected wells and unprotected springs. The number of houses that can access drinking water sources from protected springs is 90.43 percent and the remaining 8.57 percent are households with unprotected access to drinking water sources.

Households with access to unprotected drinking water sources consist of sources of drinking water from unprotected wells (3.09 percent) and unprotected springs 5.48 percent. Over the past four years, namely in 2010 to 2015 the number has changed very dynamically, but the stable percentage ranges from 3.10 - 5.44 percent.

Table 2. Household Access to Drinking Water Resources in Bergas District, Semarang Regency Central Java Province in 2010-2015

\begin{tabular}{|l|l|l|l|l|l|l|l|}
\hline Year & \multicolumn{6}{l}{ Main source of drinking water (Percent) } \\
\cline { 2 - 8 } & Packaging & Plumbing & Pumps & $\begin{array}{l}\text { Protected } \\
\text { Wells }\end{array}$ & $\begin{array}{l}\text { Unprotected } \\
\text { Wells }\end{array}$ & $\begin{array}{l}\text { Protected } \\
\text { Wells }\end{array}$ & $\begin{array}{l}\text { Unprotected } \\
\text { Wells }\end{array}$ \\
\hline 2010 & 11,71 & 8,43 & 3,93 & 47,80 & 3,10 & 19,54 & 5,44 \\
\hline 2011 & 11,71 & 8.42 & 3,97 & 47,77 & 3,09 & 19,57 & 5,46 \\
\hline 2012 & 11,71 & 8,43 & 3,97 & 47,76 & 3,09 & 19,57 & 5,46 \\
\hline 2013 & 11,68 & 8,42 & 3,98 & 47,76 & 3,09 & 19,59 & 5,47 \\
\hline 2014 & 11,68 & 8,42 & 3,98 & 47,76 & 3,09 & 19,64 & 5,48 \\
\hline 2015 & 11,65 & 8,42 & 3,98 & 47,74 & 3,09 & 19,64 & 5,48 \\
\hline
\end{tabular}

Source: Statistic Central Bureau, Semarang Regency.

Household access to drinking water sources in Bergas District is spread unevenly in all villages. The households with access to the most unprotected source of drinking water are located in Gebugan Village, which reaches 17.60 percent of the total households. Then, Godoriyo Village and Bergas Kidul. Villages with the least number of households have access to unprotected drinking water sources in Munding Village. Munding village is one of the villages located on the slopes of Mount Ungaran, the majority of households use drinking water from protected eyes, which reached 98.99 percent of the total households.

Table 3. Household Access to Unprotected Drinking Water Sources in Bergas District, Semarang Regency in 2015

\begin{tabular}{|l|l|l|l|}
\hline \multirow{2}{*}{ Villages } & \multicolumn{3}{|l|}{ The Main Source of Drinking Water is unprotected } \\
\cline { 2 - 4 } & $\begin{array}{l}\text { unprotected } \\
\text { wells }\end{array}$ & $\begin{array}{l}\text { unprotected } \\
\text { springs }\end{array}$ & Total \\
\hline Munding & 0,29 & 0,14 & 0,43 \\
\hline Pagersari & 0,88 & 6,09 & 7,97 \\
\hline Gebugan & 0,90 & 16,70 & 17,60 \\
\hline Wujil & 1,38 & 0,84 & 2,22 \\
\hline Bergas Lor & 5,33 & 0,52 & 5,85 \\
\hline
\end{tabular}




\begin{tabular}{|l|l|l|l|}
\hline Bergas Kidul & 5,31 & 7,40 & 12,71 \\
\hline Randugunting & 0,48 & 0 & 0,48 \\
\hline Jatijajar & 3,53 & 2,26 & 5,79 \\
\hline Diwak & 2,34 & 0,39 & 2,73 \\
\hline Ngempon & 6,93 & 0 & 6,93 \\
\hline Karangjati & 2,06 & 0 & 2,06 \\
\hline Wringin Putih & 1,48 & 3,08 & 4,56 \\
\hline Gondoriyo & 5,47 & 10,82 & 17,29 \\
\hline Jumlah & 3,09 & 5,48 & 8,57 \\
\hline
\end{tabular}

Source: Statistict Central Bureau Semarang Regency and Analysis Results.

In Bergas District, Semarang Regency, which is an area of industrial development, not all households can be served with access to proper drinking water sources. This is caused by the condition of the population who do not yet have a house, and residing in a non-permanent home. They use drinking water sources from unprotected springs. Whereas, it has been explained and stated in the 2015-2019 National Medium Term Development Plan or National Medium Term Development Plan document, that national priorities in one of the targets to be achieved in 2019 are the development and development of residential infrastructure programs that are $100 \%$ water supply services for the entire population Indonesia. In addition, the center of industrial development should be able to improve the standard of living of the population, including access to decent drinking water sources.

The priority program is carried out with various policies, one of the national policies to meet the access needs for the improvement of drinking water with pamsimas, which is a program initiated by the government in order to increase access to decent drinking water. The program has succeeded in increasing the number of households exposed to access to decent drinking water, around 31.14 percent for 21 years, from 1993 at the position of 37.73 percent to 68.87 percent in 2014 [20]. Nevertheless, there is indeed a difference in access to drinking water between urban and rural or peri-urban areas, namely 80.72 percent and 56.09 percent. Semarang Regency is one of the areas that entered rural areas.

\section{Conclusion}

The Everyone has the right to obtain proper clean water services, but in the study area there are still some households that use clean water from unprotected water sources to meet drinking water needs. This central industrial area is expected to improve the welfare of the population with sustainable environmental quality. In accordance with sustainable development goals which will end in 2030, which implies that everyone is served by decent water, even Indonesia expects in 2019.

\section{Acknowledgments}

Thank you to the Institute of Research and Community Service of Semarang State University for providing opportunities for research. 


\section{References}

[1] Population Reference Bureau (PRB), "2015 World Population Data Sheet," 2015.

[2] P. Hardati, "Population Mobility, Sustainable Livelihoods Strategy. Geography Approach," 2018.

[3] C. B. of Statistics, Profile of Indonesian Population Results of SUPAS 2015. Jakarta: Central Bureau of Statistics, 2016.

[4] L. M. Hunter, "Population and Environment: A complex relationship." Santa Monica, CA: RAND, 2012.

[5] C. B. of Statistics, National socio-economic survey. Jakarta: Central Bureau of Statistics, 2015.

[6] C. B. of Statistics, 2014 People's Welfare Statistics. Jakarta: Central Bureau of Statistics, 2014.

[7] World Bank, Progress on Sanitation and Drinking-water: 2013 update. 2013.

[8] A. Komarulzaman, J. Smits, and E. de Jong, "Clean water, sanitation and diarrhoea in Indonesia: Effects of household and community factors," Glob. Public Health, vol. 12, no. 9, pp. 1141-1155, 2017.

[9] A. A. Patunru, "Access to Safe Drinking Water and Sanitation in I ndonesia," Asia Pacific Policy Stud., vol. 2, no. 2, pp. 234-244, 2015.

[10] Sukartini, “Access to Water in Indonesia.," J. Quant. Econ., vol. 2, no. 0, 2016.

[11] International NGO Forum on Indonesian Development, "Sustainable Development Goals. Translation series from Outcome Document Transforming Our World: The 2030 Agenda For Sustainable Development. The President of The General Assembly. infid.," 2015.

[12] UN General Assemby, "General Comment No. 15. The Right to Water. Resolution A/RES64/29," 2010.

[13] U. N. Water, "Water security and the global water agenda: a UN-water analytical brief," Hamilton, UN Univ., 2013.

[14] RI Cabinet Secretariat, “Appendix of Republic of Indonesia Presidential Regulation Number 59 of 2017 concerning Implementation of Achievement of Sustainable Development Goals," 2017.

[15] M. Triono, "OniAccess to Clean Water in the Surabaya City Community and the Impact of the Poor Access to Clean Water on the Productivity of the City of Surabaya," J. Appl. Econ., vol. 3, no. 2, pp. 93-106, 2018.

[16] Ministry of National Development Planning. (BAPPENAS), "Summary of Metadata for Indonesian Sustainable Development Goals (SDGs) Indicators," 2017.

[17] P. Hardati, "Access to the Infrastructure of Setlement for Sustainable Development Goals in Rural District in Semarang Central Java Indonesia.," 1st ICERM UMStrengthening Synerg. Geogr. Our Futur. World, 2016.

[18] P. Hardati, "Livelihood Structure and Household Access to Drinking Water Sources in West Ungaran Sub-District Semarang Regency Central Java Province Indonesia," Int. J. Appl. Bus. Econ., 2017.

[19] Supirin, Preservation of Land and Water Resources. Yogyakarta: Andi Offset, 2002.

[20] S. Notoatmodjo, "Promotion of Health and Behavioral Sciences," Jakarta: Rineka Cipta, 2007.

[21] R. J. Kodoatie, Management of Water Resources in Regional Autonomy. Jogjakarta: Andi Offset, 2003.

[22] E. G. Wagner and J. N. Lanix, "Water Supply for Rural and Small Communication," 
Int. Inst. Environ. Dev., 1959.

[23] W. H. Organization and UniCeF, Progress on sanitation and drinking water: 2014 update. World Health Organization, 2014.

[24] M. Baiquni, Unsustainable development. Second edition. Yogyakarta: ideas, 2003.

[25] P. Hardati, "Spatial Patterns of the Relation of the Agriculture Sector to Nonagriculture and the Consequences of Household Livelihoods in Semarang Regency," UGM.

[26] Statistic Central Bureau. 2018. Bergas Sub-district in Figure 2018. Semarang. Statistic Central Bureau. 